\title{
Policy formalization of Artisanal and Small-Scale Gold Mining (ASGM) post-ratification of Minamata Convention for Sustainability (case study of ASGM Gorontalo)
}

\author{
Fenty Puluhulawa ${ }^{1, *}$ and Amanda Adelina Harun $^{2}$ \\ ${ }^{1}$ Faculty of Law, State University of Gorontalo, Gorontalo - Indonesia. \\ ${ }^{2} \mathrm{PhD}$ Student, Faculty of Law, Islamic University of Indonesia, Jogjakarta - Indonesia
}

\begin{abstract}
Indonesia ratified the Minamata Convention in Kumamoto Japan through Law No. 11 of 2017 concerning the Minamata agreement. This ratification is intended to provide protection for the environment from the use of mercury-based materials. Previous studies showed that the use of mercury in Artisanal and Small-Scale Gold Mining (ASGM) had a significant negative impact on health and the environment. The problem is whether the problems that need to be done in the application of the above regulations and maintaining environmental sustainability? The research method was carried out through related discussions and discussions with 25 relevant stakeholders, from miners, and local community, which was selected purposively. The research result was analysed qualitatively. This type of research is a combination of normative juridical and empirical juridical. For normative juridical law materials are used regarding relevant laws and regulations and cases. Data analysis was carried out descriptively. The result of the study indicate that The Minamata Convention has not been implemented as expected. The research recommended the need for policies to formalize ASGM in Gorontalo as a solution to facilitate access to mercury use. The need to educate miners about the dangers of using mercury, need alternative solutions to technology interventions for miners
\end{abstract}

Keywords: ASGM ; Minamata Convention; Policy; Sustainable.

\section{Introduction}

Indonesia is located in the form of collisions of two large plates, namely the Pacific Plate in the North and the Australian Plate in the South, this collision is needed to form a volcano (volcans arc), so that it can be used to support gold and other metal mineralization in Indonesia. [1] Mining resources include the chemical elements of minerals, ores, and all kinds of rocks including precious stones which are natural deposits. [2] Mining has characteristics, which is cannot be renewed (nonrenewable), relatively high-risk and the business has a relatively high environmental and physical impact when compared to the operation of other commodities in general [3].

Gorontalo is one of the provinces in Indonesia that has the potential for gold mineral resources, in addition to other natural resources. The potential of gold in this area can be found in several districts, namely, Gorontalo Regency, North Gorontalo Regency, Pohuwato Regency and Bone Bolango Regency. In Gorontalo Regency the potential for gold mineral resources can be found in several sub-districts with diverse potential. The management is generally done traditionally. In Pohuwato Regency the potential for gold in this area is estimated to be $1.800 .000 .000 \mathrm{~m}^{3}$, which is spread in Marisa, Taluditi,
Paguat, Popayato and Patilanggio sub-districts. In Bone Bolango Regency the potential for gold mining is in Suwawa Tengah District, East Suwawa and Bone Raya [4].

ASGM (artisanal small-scale gold mining) in North Gorontalo Regency has existed since the days of the Dutch East Indies, and has been operating since 1970, producing $286 \mathrm{~kg}$ of gold with $572 \mathrm{~kg}$ hg per year. Based on Ramli Utina's research, "mining activities traditionally processed primarily generate waste containing heavy metals such as mercury $(\mathrm{Hg})$ to contaminate the environment, and ultimately affect the biota (living organisms)" [5]. The data showed that the $\mathrm{Hg}$ element in ASGM miners in North Gorontalo Regency in Anggrek, Kwandang, Monano, Sumalata and Tolinggula districts was higher than non-miners. [6] Mercury used in the mining process not only affects the miners, but also the surrounding environment. Ramli Utina and friends' research found exposure to mercury metal in coastal birds in North Gorontalo Regency, and recommended that the government immediately stop illegal mining to prevent mercury from affecting humans. [5]

The data above shows that the law has not been optimally implemented to provide protection for humans and also the environment from pollution and damage. On

\footnotetext{
* Corresponding author: fentypuluhulawa@ung.ac.id
} 
the one side the law prohibits the use of mercury because it is harmful to humans and the environment. One of them is through the Minamata Convention which Indonesia was agreed in Japan in 2013. This Minamata Convention in 2017 has been ratified through on Law Number 11 of 2017. The ratification of the Minamata Convention has brought significant changes to the ASGM mining pattern. This Convention requires to control and eliminate the use of mercury because it is harmful to the environment and also humans, but on the other hand even though the work has a very high risk, the community still depends on working as a miner in order to meet the needs of difficult access to jobs and to fulfill family needs. Formalizing ASGM is mandated by Law Number 4 of 2009 concerning Mineral and Coal Mining which until now has not been realized. Formalization of ASGM will facilitate the government in supervising ASGM, including the use of hazardous mercury materials as mandated by the Minamata Convention. In addition, the need to educate the public and increase knowledge about the use of hazardous mercury and alternative substitutes for mercury through technological intervention [1].

\section{Research Method}

The research method was conducted through in-depth interviews and focus discussions with relevant stakeholders, namely miners, communities around the mine areas, which were selected purposively. The results of the interviews were analyzed qualitatively by the Gorontalo research location. This type of research is a combination of normative juridical and empirical juridical approaches. For normative juridical studies, legal materials are used, namely related laws and cases. Data analysis was carried out descriptively.

\section{Result and Discussion}

\subsection{Minamata Convention and ASGM in Gorontalo}

Activities related to mining materials carried out in the Bronze Age were actually metallurgy but still in a simple form. [8] The explanation above shows that awareness of Indonesia's natural wealth in the mining sector has been realized long before the era of colonialism. In the era of colonialism itself, by the Dutch government mining was regulated by the Indische Mijn Wet (IMJ) [9]. The application of the Indische Mijn Wet ended with a Substitute Government Regulations or Peraturan Pengganti Undang-Undang (Perppu) No. 37 of 1960 on Mining. In the same year a Government Regulation was issued in lieu of Law (Perppu) Number 44 of 1960 concerning Oil and Gas. Perppu No. 37 of 1960 was replaced with Law No. 11 of 1967. Law No. 11 of 1967 published in the Orde Baru period, under the leadership of President Soeharto. President Soeharto was known as the Father of Indonesian Development, because during the administration of President Suharto a new development began. Law No. 11 of 1967 was considered as a form of regulation concerning mining which was more in accordance with the 1945 Constitution of the Republic of Indonesia. Law No. 11 of 1967 also to accelerate the implementation of the national economic development.

Article 33 paragraph (3) of the 1945 Constitution of Indonesia places emphasis on several important points, namely; control by the state; and used for the greatest prosperity of the people. Bagir Manan, formulated the scope of the definition of "controlled by the state", among others, mastery of such ownership by the state, meaning that the state through the central government is the sole authority to determine the authority over it including the earth, water and natural resources contained therein. [10] In addition, in Article 33 paragraph (3) it is also mentioned "used for the greatest prosperity of the people". This means that all natural resource management activities must be oriented towards the people's prosperity. The Constitutional Court in several of its decisions has interpreted the term controlled by the state, which includes the meaning of mastery by the state in the broadest sense, sourced and derived from the concept of popular sovereignty. [11] The people collectively give a mandate to the state to make the greatest prosperity of the people. [11]

Coal mining activities as one of the uses of natural resources are basically part of the implementation of economic development which essentially refers to the national development goals, namely improving the welfare of the community [12]. Article 33 of the 1945 Constitution of Indonesia justifies the exploitation of natural resources on the basis of philosophical considerations (the basic spirit of the economy is a joint venture and kinship) strategically, politically (preventing monopolies and oligopoly that harm the state), economy (efficiency and effectiveness), and for the general welfare and as much as possible the prosperity of the people [13]. The important points above should be reflected in various laws related to natural resource management, including the Mining Law. One form of mastery of natural resources for people's prosperity is realized in the form of Artisanal Small-scale Gold Mining (ASGM). The nature of small-scale mining is a simple and smallscale mining business, does not use sophisticated equipment, the production is sufficient for the daily needs of miners, the area is very limited, that is not more than 5 (five) hectares and the mine life is relatively short and diverse character [14]. The mining business has helped local communities to improve their economic level, even though income from community mining activities is uncertain [15].

The miners in ASGM do get economic benefits from the sale of gold, but the use of mercury and the process of waste disposal without being processed first proved to have polluted the surrounding environment and the body of the population. [15] Environmental pollution caused by community mining is one of the problems related to community mining today. The idea of writing this article arose from the desire to regulate ASGM which has been highlighted so far has the potential to have a negative 
impact on the environment by optimizing the function of law as a tool of social control.

In certain numbers, the use of food in mining activities can have a negative impact on miners and the environment. The Minamata case that happened in Japan should be a very valuable lesson for everyone to always protect the environment and humans and other creatures for its sustainability. In the early 1950 s, massive population poisoning of methyl mercury ( $\mathrm{MeHg}$ ) living around Minamata Bay, on the southwest coast of Japan's Kyushu island, caused severe neurological disease, this neurological disorder was named Minamata disease (MD). [16] "The primary route of exposure to $\mathrm{MeHg}$ in this incident was the consumption of fish and shellfish contaminated with a high concentration of $\mathrm{MeHg}$ ". [16]

The impact of mercury on health including digestive and nervous system disorders, large and repeated exposure can cause fatal health damage. [17] East and Southeast Asia contribute $40 \%$ of mercury emissions to the air. [18] The negative impact of mercury raises awareness from the world community to regulate the use of mercury. The United Nations Environmental Program (UNEP) has initiated a conference attended by representatives of the Intergovernmental Negotiating Committees (INC) from each discussing mercury and giving birth to the Minamata Convention on Mercury (Minamata Convention on Mercury). [17] The Minamata Convention is intended to protect human health and the environment from the effects caused by the release of mercury compounds. For Indonesia, the ratification of the convention is an advance in order to provide protection for sentient beings. The Minamata Convention has a binding power for all Indonesian citizens to adhere to and implement because it has been agreed and even ratified through Law No. 11 of 2017 on Ratification of the Minamata Convention on Mercury.

Based on the explanation of Law No. 11 of 2017, the general section, that Mercury or mercury is one of the heavy metals that is very dangerous for health and the environment because it is toxic, persistent, bioaccumulating and can move long distances in the atmosphere, with the help of bacteria in sediments and waters, mercury changes being methyl mercury which is more dangerous for health because it enters the food chain. Explanation of the Law No. 11 of 2017, states the obligation for the state as one of the parties, not to be allowed to use primary mercury mining since the signing of the convention, the prohibition of producing, importing or exporting mercury-containing products listed in Part 1 Appendix A of the Convention, is mandatory take steps to prevent the inclusion of mercury in assembled products that are manufactured, imported, exported, not permitted at conventions. Article 7 Appendix C which specifically applies to ASGM. Article in this convention contains the agreement of the parties to take steps to reduce and if it can eliminate the use of mercury and mercury compounds and emissions and emission compounds from such processing mines. It was agreed for the parties to compile and implement and submit their development once every 3 (three) years through reports in accordance with Article 21 of the convention.
The prohibition on the use of mercury regulated in the Minamata Convention on Mercury includes the use of mercury in the mining environment. In Article 2 Minamata Convention on Mercury, artisanal small-scale gold mining (ASGM) is mining or gold mining carried out by individual miners or small-scale companies with limited capital investment and production. ASGM tends to be carried out on a small scale and in a traditional way, because it is done by the local community with limited equipment and knowledge.

ASGM or small-scale gold mining can be defined as mining activities carried out by surrounding communities on a small scale. This is as revealed by Inswiasri and Hendro Martono:

"The existence of this gold mining activity often creates other problems that afflict local community groups who generally live in poverty and do not have enough education. They also use existing natural resources such as mining gold which is processed in a very simple way. This is called a small-scale gold mining (ASGM) group, a people's gold mine or a traditional gold mine" [19]

Based on Law No.4 of 2009 concerning Mineral and Coal Mining, the small scale referred to here is a maximum of 25 hectares. Based on this rule, which is recognized as ASGM is a region where mining activities have been carried out by the people for at least 15 years. This means that the area that can be recognized as a people's mine is a small-scale mining area that has been cultivated by the people for at least the last 15 years. ASGM itself needs to get permission from the Regional Government.

ASGM and its licensing procedures are regulated in Law No. 4 of 2009, in practice ASGM in Gorontalo generally had no licenses (illegal). Have similarities with other ASGM in Indonesia. Besides some of these problems, the constraints to implementing the rules for miners helped to aggravate the situation and conditions. This causes people's mines tend to be carried out without permission and are prone to accidents and work safety, potentially causing pollution and uncontrolled environmental damage. [20] Whereas if guided by Law number 4 of 2009 on Mineral and Coal Mining, the permit for community mining has been regulated in the third part. This means that all people's mining has the opportunity to be able to apply for permission. Even in Article 22 of the Capital Market Law, it is stipulated that the determination of community mining areas can be carried out in areas where people's mining activities are carried out at least 15 (fifteen) years.

The problem of mining that is carried out without permission is indeed a lot in Indonesia. Based on data submitted by the Ministry of Environment and Forestry (in bahasa Indonesia called KLHK), field verification in September 2015 there were 302 mining locations carried out without permission. [21] In Indonesia, the existence of several ASGMs even existed before Indonesian independence in 1945, namely before the era of Law No. 4 of 2009 and Law No. 11 of 1967. ASGM which tends to be managed by the surrounding people in traditional ways has an impact on the conventional management of 
the ASGM area. As indicated by ASGM not having a permit, it is difficult to find data on the development of the number of mines in the area, the area of community mining areas, and also the difficulty in controlling the use of mercury in these activities. Estimates of the number of locations in 2012 show data as in the Table 1

Table 1. List of Artisanal Small-Scale Gold Mining in Gorontalo Province, December 2012

\begin{tabular}{|c|c|c|c|c|c|c|c|}
\hline \multirow{2}{*}{ Regency } & \multirow{2}{*}{ Sub-Districts } & \multirow{2}{*}{$\begin{array}{c}\text { Estimated } \\
\text { Number of } \\
\text { Miners } \\
\text { (person) }\end{array}$} & \multirow{2}{*}{$\begin{array}{c}\text { Number } \\
\text { of } \\
\text { Tromol } \\
\text { (unit) }\end{array}$} & \multirow{2}{*}{$\begin{array}{c}\text { Estimated } \\
\text { Area } \\
(\mathrm{Ha})\end{array}$} & \multirow{2}{*}{$\begin{array}{l}\text { Mining } \\
\text { System }\end{array}$} & \multicolumn{2}{|c|}{$\begin{array}{c}\text { Location } \\
\text { Coordinates }\end{array}$} \\
\hline & & & & & & $\mathrm{X}$ & $\mathrm{Y}$ \\
\hline Bonebolango & $\begin{array}{l}\text { - Waluhu } \\
\text { - Mopuya } \\
\text { - Tumbullilato } \\
\text { - Mohutango } \\
\text { - Tulabolo }\end{array}$ & $\begin{array}{l}1.000 \\
100 \\
5.000 \\
500 \\
5.000\end{array}$ & $\begin{array}{l}20 \\
15 \\
5 \\
20 \\
100\end{array}$ & $\begin{array}{l}10 \\
7 \\
5 \\
15 \\
25\end{array}$ & $\begin{array}{l}\text { Hole } \\
\text { Hole } \\
\text { Hole } \\
\text { Hole } \\
\text { Hole }\end{array}$ & $\begin{array}{l}123,272 \\
123,349 \\
123,349 \\
123,309 \\
123,368\end{array}$ & $\begin{array}{l}0.325 \\
0,356 \\
0,382 \\
0,445 \\
0,325\end{array}$ \\
\hline Gorontalo & $\begin{array}{l}\text {-Totopo } \\
\text {-Tamaela }\end{array}$ & $\begin{array}{l}50 \\
1.000\end{array}$ & $\begin{array}{l}5 \\
1\end{array}$ & $\begin{array}{l}5 \\
2\end{array}$ & $\begin{array}{l}\text { Use hole } \\
\text { Spray \& tray }\end{array}$ & $\begin{array}{l}122,666 \\
122,668\end{array}$ & $\begin{array}{l}0,562 \\
0,816\end{array}$ \\
\hline $\begin{array}{l}\text { North } \\
\text { Gorontalo }\end{array}$ & $\begin{array}{l}\text {-Ilangata } \\
\text {-Buladu } \\
\text {-Kasia } \\
\end{array}$ & $\begin{array}{l}100 \\
100 \\
100\end{array}$ & $\begin{array}{l}20 \\
2 \\
4\end{array}$ & $\begin{array}{l}15 \\
50 \\
20\end{array}$ & $\begin{array}{l}\text { Spray \& tray } \\
\text { Hole \& tray } \\
\text { Hole }\end{array}$ & $\begin{array}{l}122,776 \\
122,511 \\
122,354\end{array}$ & $\begin{array}{l}0,84 \\
0,936 \\
0,931\end{array}$ \\
\hline Boalemo & \begin{tabular}{|l|}
-Saripi \\
-Botuwonggu \\
bu
\end{tabular} & $\begin{array}{l}500 \\
500\end{array}$ & $\begin{array}{l}1 \\
1\end{array}$ & $\begin{array}{l}45 \\
5\end{array}$ & $\begin{array}{l}\text { Tray \& } \\
\text { spray } \\
\text { Spray \& tray }\end{array}$ & $\begin{array}{l}122,511 \\
122,231\end{array}$ & $\begin{array}{l}0,641 \\
0,863\end{array}$ \\
\hline Pohuwato & $\begin{array}{l}\text {-Pani and } \\
\text { surrounding } \\
\text { area } \\
\text {-Batudulanga } \\
\text {-Makarti Jaya }\end{array}$ & $\begin{array}{l}100 \\
100\end{array}$ & $\begin{array}{l}1 \\
1\end{array}$ & $\begin{array}{l}3 \\
15 \\
\end{array}$ & $\begin{array}{l}\text { Spray, tray } \\
\text { Tray } \\
\text { Spray \& tray }\end{array}$ & $\begin{array}{l}122,027 \\
121,777\end{array}$ & $\begin{array}{l}0,541 \\
0,731\end{array}$ \\
\hline Jumlah & 15 areas & 14,250 & 216 & 272 & & & \\
\hline
\end{tabular}

Judging from the status of ownership, ASGM in Gorontalo has similarities with ASGM in several regions. The results of research in several places that the ownership status of ASGM is individual, group, family mining, or cooperatives with rudimentary and processing methods. [22] In Gorontalo, community mining is owned by individuals, groups or families. The mine owner is not a mine worker. Mine workers are those who receive wages from the results of mining work. The results of mining work are reduced by costs during processing with varying happiness from the mine owner, the right hand of the mine owner, but for members of the mine owner to use the profit sharing system according to the agreement. The ASGM area is generally owned by individuals or groups, in part of the mining area of the owner of ASGM.

\subsection{Formalization ASGM Post-Ratification Minamata Convention}

In theory, the law has two functions, namely, as a tool of social control and as a tool of social engineering. Law as a tool of social control, as stated by Abdul Manan, is a function to control behavior and human actions so that they do not act against legal, religious and moral norms. [23] The concept of legal functions as a tool of social engineering comes from Roscoe Pound. If the function of law as a tool of social engineering in the context of Indonesia, legal functions according to Mochtar Kusumaatmadja are interpreted as a means of driving renewal in society. [24] Mochtar's concept emphasizes the establishment of legislation by the legislative body in this case the House of Representatives or Dewan Perwakilan Rakyat (DPR), which is intended to initiate the construction of the new community that wants to be realized. [25] In simple terms, the two types of legal functions can be interpreted as legal functions as a tool to change society and / or society to change the law. [26]

If the two legal functions are linked to the problem of community mining, then law as a tool of social control should be able to control people's mining behavior so that it does not have the effect of damage to the environment. The function of law as social engineering aims to change society in accordance with expectations, so that in the context of community mining the function of law as a tool of social engineering is seen as a legal function to change the pattern of mining activities at the current ASGM to be more environmentally friendly. If the two legal functions above work well, then the negative impact should not occur if the two legal functions run.

The Minamata Convention has been agreed upon, ratified and stipulated through Law No. 11 of 2017. Ratification does not mean that the provisions in the convention bind the people of that country or bind the country to its people, [27] so that every country that has ratified a convention must prepare legal instruments in accordance with the provisions of the convention. [28] In the Minamata Convention, Indonesia has ratified and stated it in Law No. 11 of 2017, so that it has binding legal powers for the country and its people. The provisions of the Minamata Convention even though it 
has been stated in the Law and has binding legal powers, but in the level of practice it is difficult to be fully realized. The Minamata Convention regulates the use of mercury, including a ban on the use of mercury in mining areas. These provisions have not been fully implemented. The results of interviews with miners that mercury is still used in processing gold mining products since the past until now.

Ramli Utina said "Mercury is used in amalgamation gold processing traditional caused surface tension of mercury higher than water but less than gold, this allows the properties of metals can absorb mercury into gold particles, in addition to more effective, easy, inexpensive and available in the market". The superiority of mercury and the availability of mercury in the market make mercury in demand by miners, especially ASGM miners who are run without permission. [5]

ASGM is the largest consumer of mercury in the world. [29] UNEP (United Nations Environment Program) estimates that mercury use at the annual ASGM is 727 tons or $35 \%$ of the world's total anthropogenic emissions of mercury. [22] This condition has a negative impact on health and the environment. UGM has a positive impact which is a source of income for the population, as well as reducing unemployment. ASGM is a source of income, [30] the existence of ASGM is part of the state's control of natural resources for the greatest possible prosperity of the people as stated in the written constitution of Indonesia. The Constitutional Court in several of its decisions has interpreted the term controlled by the state, which includes the meaning of control by the state in a broad sense, sourced and derived from the concept of popular sovereignty. [11] The people collectively give a mandate to the state to make the greatest prosperity of the people. [11] ASGM Gorontalo, according to the 2012 Mining Service data, absorbs a local workforce of around 14,250 people. Mine locations are spread over 15 locations with mining systems carried out with holes, spray and bone. [31]

ASGM is a manifestation of natural resources for the prosperity of the people, but on the other hand, the tendency of mercury use in ASGM has a negative impact on the health of miners and environmental pollution. Environmental issue data caused by ASGM. ASGM as defined in the Minamata Convention, and Law No. 4 of 2009 is a mining area on a small scale. In general, ASGM is also managed in a more conventional way compared to mining managed by the company. At ASGM in Gorontalo, ASGM is managed simply by using makeshift equipment. Limited funds, conventional management, and supervision that do not provide a gap for ASGM use mercury which should be prohibited. There are a number of cases related to health problems caused by Mercury in the world. Health problems caused by mercury do not only threaten miners who interact directly with mercury, but also with the surrounding environment. The case in Minamata, Japan where pollution by the disposal of industrial waste contains methylmercury into the lake and causes fish on the lake to be polluted, so that a number of babies suffer from serious brain damage. [32] This is caused by babies born to mothers who have consumed fish contaminated with mercury. In Iraq, Guatemala and Pakistan thousands of people died because they consumed grains contaminated with methyl-mercury from insect pest control. [32]

The policy in implementing the Minamata Convention will not be effectively implemented, if it is not carried out in an integrated manner, it involves stakeholders to also have concern for the danger of the danger caused by the use of these substances. A number of factors that are obstacles to the application of this convention can be derived from 3 (three) aspects, both of which come from the substance, structure and culture of society. According to Friedman, [33] the structure of a system is it skeleta frame work; its is the permanent skape, the institutional body off the system the tough, rigid bones that keep the process flowing within bounds. Friedman [33] the substance is composed of substantive rules and rules about how institution should behave. Friedman [33] on Legal Culture, System- their beliefs, values, ideas and expectations.

The substance of the ban on the use of mercury in mining is contained in the Minamata Convention as stipulated in Law No. 11 of 2017. In addition to Law No. 11 of 2017 , another rule that prohibits the use of mercury that can damage the environment is in Law No. 4 of 2009 concerning Mineral and Coal, and Law No. 32 of 2009 concerning Environmental Protection and Management. In the Mineral and Coal Law, as well as the Environmental Protection and Management Act, there is no specific prohibition on theft, but the prohibition on the use of materials that are dangerous and potentially damaging to the environment.

One of the problems related to the substance of regulating the use of mercury is not regulated in detail. Both in the Mineral and Coal Law and in the Environmental Protection and Management Act, mercury compounds are not mentioned in writing as compounds that are prohibited from being used in the mining process. The prohibition on the use of mercury is only contained in the rules under the Act.

The prohibition on the use of mercury is stated in the Minister of Energy and Mineral Resources Circular Number 6E / 32/ MEM.B / 2017 concerning the Prohibition of Using Mercury in Gold Mining dated April 21, 2017 and Circular Menkopolhukam Number: B-20 / Menkopolhukam / De-V / KM / 04 / 7/2017 concerning Illegal Distribution and Use of Mercury in Mining Activities dated May 14, 2017. In some regions in Indonesia, the prohibition on mercury is regulated further by Regional Regulations. In West Kalimantan, mercury is regulated in the West Kalimantan Provincial Regulation No. 4 of 2007 Controlling the Distribution and Use of Mercury and the like in West Kalimantan. These regional regulations have regulated the distribution of mercury, so that trade and distribution of mercury can be controlled.

Based on the results of interviews, ASGM miners get mercury through illicit circulation. Transactions of illicit mercury circulation in ASGM miners have an impact on the difficulty of preventing the use of mercury in the ASGM environment. If viewed in terms of structure, supervision of the use of mercury in the ASGM 
environment is considered not optimal. Based on the results of interviews, they are not difficult to get mercury. Mercury is easily obtained as long as it has worked with gold shop owners when it comes to processing mining products.

The last subsystem is legal culture, namely the community response to a rule. Basically, ASGM is a source of community livelihood, so its existence is needed. ASGM is even managed more simply than ordinary mining, but ASGM can provide a source of income for the community. Mercury is cheaper and available on the market, so it is an option that is considered better by miners regardless of the health hazards and environmental damage created. ASGM generally conducts mining in areas that have been mined for generations. This raises the opinion that the mine belongs to the people, which has been managed for a long time, so it does not need permission from the government. Moreover, if ASGM is in an area / land that is also inherited from generation to generation. ASGM which is managed without permission, will make it difficult for the government to oversee the ASGM. The absence of supervision can trigger the invisible violations that occur in it, including the use of mercury in ASGM, which cannot be monitored and controlled.

\subsection{Alternative Approach in Formalizing Artisanal Small-Scale Gold Mining (ASGM)}

Alternative solutions to the problem of mercury use in the ASGM environment can be reviewed from 3 subsystems in Lawrence Friedman's opinion. If seen from the substance, regulations that regulate the circulation of mercury in Gorontalo Province are needed. This is intended to prevent the circulation of mercury illegally, and to control the distribution of mercury in ASGM. Formalization is one alternative solution in minimizing the impact of mercury use. The formalization step can be carried out through the stages of determining people's mining areas through spatial planning as in the UUPMB. At that stage the zin of the people's mining business will only be given to the designated area of the ASGM area. Thus, the status of community mines (ASGM) is a mine that has permits and is not illegal as it is today. Supervision of licensed ASGM will be easier to do than unlicensed mines, including the use of hazardous compounds such as mercury and the like.

ASGM provides jobs so that it becomes a source of income for the people. The ASGM area which has been managed for generations is one of the reasons why some of the ASGM areas tend to be carried out by permission. [7] Based on the FGD (Focus Group Discussion) results, it was found that miners generally knew that the use of mercury in mining was dangerous, but still preferred to use mercury, because it did not have an alternative choice but to use the compound. This needs to be done by implementing alternative technologies that can be implemented by educating the public to switch to technologies that are more environmentally friendly.

\section{Conclusion}

The Minamata Convention limits, reduces and even eliminates the use of mercury, including in Artisanal and Small-Scale Gold Mining (ASGM). ASGM in Gorontalo still uses mercury in the gold refining process. This shows the application of the Minamata Convention through Law No. 11 of 2017 has not been implemented as expected. The results showed that ASGM Gorontalo operates without permission, making it difficult to supervise the use of mercury. Community needs, especially miners for mercury, and market availability make the chain of mercury circulation in Gorontalo difficult to decide.

\section{Recommendation}

Formalization of mining is an alternative policy solution in minimizing and even preventing the use of mercury compounds as mandated by the Minamata Convention. It is necessary to educate miners about the dangers of using mercury. Technology alternatives are needed that can substitute the use of mercury compounds as hazardous compounds that are contrary to the law.

Acknowledgments to the Indonesian Ministry of Research, Technology and Higher Education and the Gorontalo State University LPPM for supports for his research, Contract Number: 58/UN47.D2/PL/2014, and Contract Number 583/UN47.D/PL/2018

\section{References}

1. Sujono, Geologi dan Mula jadi Emas, Bandung: Puslitbang Mineral dan Batubara (2004)

2. S. HS, The Law Mining in Indonesia third Revision, Jakarta: PT Rajagrafindo Persada (2007)

3. A. Sutedi, The Law Mining, Jakarta: Sinar Grafika, (2011)

4. G.O.G. Province, Gorontalo Provincial Government Investment, ESDM and Transmigration Agency, (2018)

5. R. Utina, A. Katili, Ramli Utina, and Abubakar Sidiki Katili, 2014, Inventory of Water Bird Species Which Accumulate Mercury from Mining Waste in Coastal Area North Gorontalo Regency, Indonesia, Int. J. of Waste Resources 4(1) (2014)

6. Y. Arifin, et. al, Heavy Metal Consentrations in Scalph Hair of ASGM Miners and Inhabitants of The Gorontalo Utara Regency, IOP Conference Beijing (2017)

7. A. Redi, The Dilemma of Law Enforcement of Mineral and Coal Mining Without Permits in SmallScale Mining, Journ. Rechtsvinding 5(3) (2016)

8. J.T. Soedarjono, The Mining Law, Jakarta: Universitas Indonesia (2006)

9. A. Saleng, The Mining Law, Yogyakarta: UII Press, (2004) 
10. G.D.H. Wibowo, The Legal and Institutional Aspects in Increasing the Efficiency and Effectiveness of Management of Coastal Areas," Jurnal Hukum 1(16) (2009)

11. H. Juwana, Ikhwal Dikuasai Negara, Nasional Kompas (2015)

12. N. Listiyani, The Impact of Mining on the Environment in South Kalimantan and Its Implications for Citizens' Rights, Al' Adl 9(1) (2017)

13. R.J. Mawuntu, The Concept of State Control Based on Article 33 of the 1945 Constitution and the Decision of the Constitutional Court, Jurnal Hukum Unsrat 20(86) (2012)

14. J.D. Manik, The Mining Management which Has Environmental Impacts in Indonesia, Jurnal Promine 1(1) (2013)

15. R. Larasati, P. Setyono K.A. Sambowo, The Economic Valuation of Externalities of Mercury Use in People's Gold Mining and The Role of Local Governments in Overcoming Mercury Pollution (A Case Study of People's Gold Mining in Kokap Kulon Progo Sub-District), Jurnal Ekosains 4(1) (2012)

16. S. Ekino, M. Susa, T. Ninomiya, K. Imamura, T. Kitamura, Minamata Disease Revisited: An Update On The Acute and Chronic Manifestations of Methyl Mercury Poisoning, Journal of the Neurological Sciences no. 262, 131-144 (2007)

17. Y. Setiawan, The Valuation of Control of Coal Boiler Emissions in the Paper Industry and Estimation of Mercury Emissions (Hg), Jurnal Selulosa 7(1) (2017)

18. A. Giang, L. Stokes, D.G. Streets, E.S. Corbitt, N.E. Selin, Impacts of The Minamata Convention on Mercury Emissions and Global Deposition from Coal-Fired Power Generation in Asia, Environmental Science and Technology 49(9) (2015)

19. Inswiasri, H. Martono, The Contamination in the People's Gold Mining Area, Media Litbang Kesehatan XVLL(3) (2007)

20. M.O.H. Miharja, The Legal Implications Regarding People's Mining in the Minerba Sector in Indonesia, Privat Law Journal 7 (2015)

21. K.L. Hidup, Ministry of Environment, [Online]. Available: http://www.menlh.go.id/deklarasi- pengendalian-pencemaran-dan-kerusakanlingkungan-akibat-pertambangan/. [Accessed 1 June 2018]

22. F.K.F. Macdonald, M. Lund, M. Blanchette, C. McCullough, Regulation of Artisanal Small Scale gold Mining (ASGM) In Ghana and Indonesia as Currently Implemented Failes to Adequately Protect Aquatic Ecosystem, The International Mine Water Association (IMWA) Congress (2014)

23. S. Sidik, The Impact of the Information and Electronic Transaction Law (ITE Law) on Legal and Social Change in the Community, Jurnal Ilmiah Widya 1(1) (2013)

24. M. Kusumaatmadja, Law Function in a Developing Society, Jakarta: BPHN Binacipta (1978)

25. N. Surbakti, Problems with Law Enforcement of the Law on the Elimination of Domestic Violence, Jurnal Ilmu Hukum, 9(1) (2006)

26. E. Rosana, Law and Community Develoment, Jurnal TAPis 9(1) (2013)

27. D. Agus, Position of the ILO Convention as a Source of Indonesian Labor/Employment Law, Jurnal Hukum Internasional, 1(1) (2013)

28. A. Khakim, Introduction to Labor Law, Bandung: Citra Aditya Bakti (2003)

29. N. Steckling et al., Global Burden Disease of Mercury Used in Artisanal Small-Scale Gold Mining, Annals Global Health, 83(2) (2017)

30. M. Salo, et. al, Local Perspectives On The Formalization of Artisanal and Small-Scale Mining in The Madre de Dios Gold Fields, Peru, The Extractives Industry and Societiy 3, 1058-1066 (2016)

31. D.P.P. Gorontalo, Gorontalo Province Mining Service Data in 2012, Gorontalo Province Mining Service (2012)

32. D.Z. Herman, The overview of Tailings Contains Pollutant Elements (As), Mercury (Hg), Lead (Tb), Cadmium (Cd) from the Residue of Metal Ore Processing, Jurnal Geologi Indonesia 1(1) (2006)

33. H. Basri, Position of Islamic Sharia in Aceh in the Indonesian Legal System, Kanun Jurnal Ilmu Hukum 55(13) (2011) 